\title{
Heavy Metals Concentration in Sediments of South Brittany Waters, France: An Ecological Risk Assessment Approach
}

\author{
Meng Chuan Ong1,2,3*, Hui-Juan Pan ${ }^{4,5^{*}}$, Noor Azhar Mohamed Shazili2 ${ }^{2}$, David Menier6, \\ Virginie Dupont ${ }^{7}$, Sidonie Révillon ${ }^{8,9}$, Alexandra Connell ${ }^{10}$
}

\begin{abstract}
${ }^{1}$ Faculty of Science and Marine Environment, Universiti Malaysia Terengganu, Kuala Nerus, Terengganu, Malaysia ${ }^{2}$ Institute of Oceanography and Environment, Universiti Malaysia Terengganu, Kuala Nerus, Terengganu, Malaysia ${ }^{3}$ Ocean Pollution and Ecotoxicology (OPEC) Research Group, Universiti Malaysia Terengganu, Kuala Nerus, Terengganu, Malaysia ${ }^{4}$ Institute of Earth Sciences, College of Ocean Science and Resource, National Taiwan Ocean University, Chinese Taipei ${ }^{5}$ Center of Excellence for Ocean Engineering, College of Engineering, National Taiwan Ocean University, Chinese Taipei ${ }^{6}$ Laboratoire Géosciences Océan (LGO), Université Bretagne Sud, Vannes, France

${ }^{7}$ Département Sciences de la Matière et de la Vie, Université Bretagne Sud, Vannes, France

${ }^{8}$ UMR 6538 Laboratoire Géosciences Océan, Institut Universitaire Européen de la Mer, Place Nicolas Copernic, Plouzané, France ${ }^{9}$ SEDISOR, Institut Universitaire Européen de la Mer, Place Nicolas Copernic, Plouzané, France

${ }^{10}$ Université de Bordeaux-UMR CNRS 5805 EPOC, Pessac, France

Email: ^ong@umt.edu.my, *hjpan76@gmail.com
\end{abstract}

How to cite this paper: Ong, M.C., Pan, H.-J., Shazili, N.A.M., Menier, D., Dupont, V., Révillon, S. and Connell, A. (2021) Heavy Metals Concentration in Sediments of South Brittany Waters, France: An Ecological Risk Assessment Approach. Open Journal of Marine Science, 11, 55-68.

https://doi.org/10.4236/ojms.2021.111004

Received: October 27, 2020

Accepted: January 18, 2021

Published: January 21, 2021

Copyright $\odot 2021$ by author(s) and Scientific Research Publishing Inc. This work is licensed under the Creative Commons Attribution International License (CC BY 4.0).

http://creativecommons.org/licenses/by/4.0/

(c) (i) Open Access

\begin{abstract}
Distribution patterns of selected heavy metals content in sediments from the Bay of Quiberon and Gulf of Morbihan were studied to understand the current heavy metals contamination due to urbanization and mariculture activities in the coastal area. Therefore, a survey was conducted and 196 sediments collected were characterized for heavy metals content using Inductively Coupled Plasma-Mass Spectrometry (ICP-MS) after mix acid digestion process. The distribution maps of the concentrations of the heavy metals studied were produced as an isopleth map based on data interpolation by the ArcGIS software application. The association with the adverse effects on aquatic organisms was determined by the classification of the sediment according to the sediment quality guidelines. Therefore, two approaches were employed namely: direct comparison with Sediment Quality Guidelines (SQGs) by USEPA (United States Environmental Protection Agency) and comparison with other numerical SQGs, threshold effect level/probable effect level, and effect range low/effect range medium. In order to estimate the effect of multiple contaminations of heavy metals, the mean-ERM-quotient was calculated at each sampling point.
\end{abstract}




\section{Keywords}

Heavy Metals, Bay of Quiberon, Gulf of Morbihan, Sediment, Sediment Quality Guidelines

\section{Introduction}

Human pressures on the ocean are thought to be rising globally in diverse and profound ways [1] [2]. The demand for marine space and resources is expanding as the population grows and migrates toward coastal areas, resulting in new challenges and risks for marine ecosystems [3] [4]. Nowadays, estuary and coastal environments are contaminated through activities such as tourism, and areas such as harbors and industrials sites. These release elevated concentrations of heavy metals, nutrients, organic pollutants, and radionuclides into the marine environment [5]. The pollution of coastal zones near metropolitan areas, caused by this anthropogenic waste is due to the large human population and the enormous amount of sewage discharged into coastal waters [6]. The addition of waste products into rivers and estuaries, particularly those in industrial and populated centres, has led to a significant increase in contamination caused by heavy metals [7].

Heavy metals, such as copper $(\mathrm{Cu})$, zinc $(\mathrm{Zn})$, cadmium $(\mathrm{Cd})$ and lead $(\mathrm{Pb})$, have a great affinity for sediment in the aquatic environment. These pollutants are persistent contaminants that bioaccumulate throughout the food chain with potential toxicity for aquatic organisms and humans [8] [9]. It is difficult to remove the toxic heavy metals once they enter the body of organisms [10] [11]. Furthermore, heavy metals are enriched at consecutive trophic levels of food chains resulting in biomagnification of these chemicals in the food web [12] [13]. Top predators, such as marine mammals and humans, may be at areater risk from heavy metals due to their top position in trophic chains, resulting in adverse health effects [14].

For example, lead can penetrate the body and cell membranes easily, and is associated with nervous system disorders and lead encephalopathy [15]. Long-term exposure or intake of food with a high concentration of Cd may cause itai-itai disease and kidney damage [16]. It occurred in numerous residents of the Jinzu River basin in Toyama Prefecture, Japan, a region extremely polluted with Cd that originated from a zinc mine located upstream [17]. Moreover, green-colored oysters as a result of $\mathrm{Cu}$ contamination have been found in several estuaries and harbors around the world, including the USA [18], Spain [19], Chinese mainland [20] [21], and Taiwan area [22]. Chronic $\mathrm{Cu}$ toxicity can cause liver disease and critical neurological damage [23]. Zn has been considered to be relatively nontoxic; however, taking high levels of $\mathrm{Zn}$-contaminated food can damage the pancreas and disturb protein metabolism, causing health problems, such as stomach cramps, bloody urine, liver failure, nausea, and anemia [24] [25]. As a 
consequence, a systematic assessment of heavy metal pollutants is critical, especially for the coastal area.

Coastal areas are sensitive to both climate changes and human impacts, which make these areas ideal for studying environmental changes and the sequence of coastal sediments, and have become attractive targets for documenting paleoenvironmental changes. The Bay of Quiberon and Gulf of Morbihan on the south coast of Brittany Region, France, are an excellent example of the coastal sea with high terrestrial influence, a semi-enclosed bay, surrounded by densely populated areas and mariculture activities. Such an investigation is required if the environmental impacts of the region are to be understood quantitatively and qualitatively.

Accumulation of heavy metals in surface sediments from industrial effluents and urban discharged into the river without proper cleaning is easily identified by heavy metals spatial variations in sediments [26]. In this exploration, surficial spatial distributions of selected heavy metals; $\mathrm{Cu}, \mathrm{Zn}, \mathrm{Cd}, \mathrm{Pb}$ (identified as priority contaminants in aquatic systems by the European Community (EC) Water Framework Directive 2000/60/EC) [27] were characterized in the surficial sediments which reflects the recent input to evaluate the contamination level resulting from anthropogenic inputs. This EC work recommends the monitoring of fluvial loads of heavy metals as a tool for sustainable management in the aquatic ecosystem [28].

Information on contamination background is required for managers and policymakers to make strategic regulations, guidelines, and monitor progress towards management objectives. In order to establish such a knowledge, the present study investigates the spatial distribution of four heavy metals $(\mathrm{Cu}, \mathrm{Cd}$, $\mathrm{Pb}$ and $\mathrm{Zn}$ ) at 196 sampling points in the Bay of Quiberon and Gulf of Morbihan surficial sediments. The adverse effects on aquatic organisms were determined by direct comparison with the Sediment Quality Guidelines (SQGs) and the sediment toxicity and ecological risk indices, namely the effect low range (ERL)/effect range median (ERM), and the threshold effect level (TEL)/probable effect level (PEL) values. In order to estimate the effect of multiple contaminations of heavy metals in the study area, the mean-ERM-quotient was also calculated at each sampling point.

\section{Materials and Methods}

\subsection{Study Area}

The Bay of Quiberon is a large open-sea area on the south coast of Brittany, consisting of two additional areas with an equivalent surface area of approximately $120 \mathrm{~km}^{2}$ (Figure 1). The bay is roughly triangular, almost completely surrounded by land on the north and east sides; open to the south with the Gulf of Morbihan to the north-east, and the narrow peninsula of Quiberon providing protection from the Atlantic Ocean to the west. The Belle, Houat, and Hœdic islands add to the protection of the bay [29] [30]. 


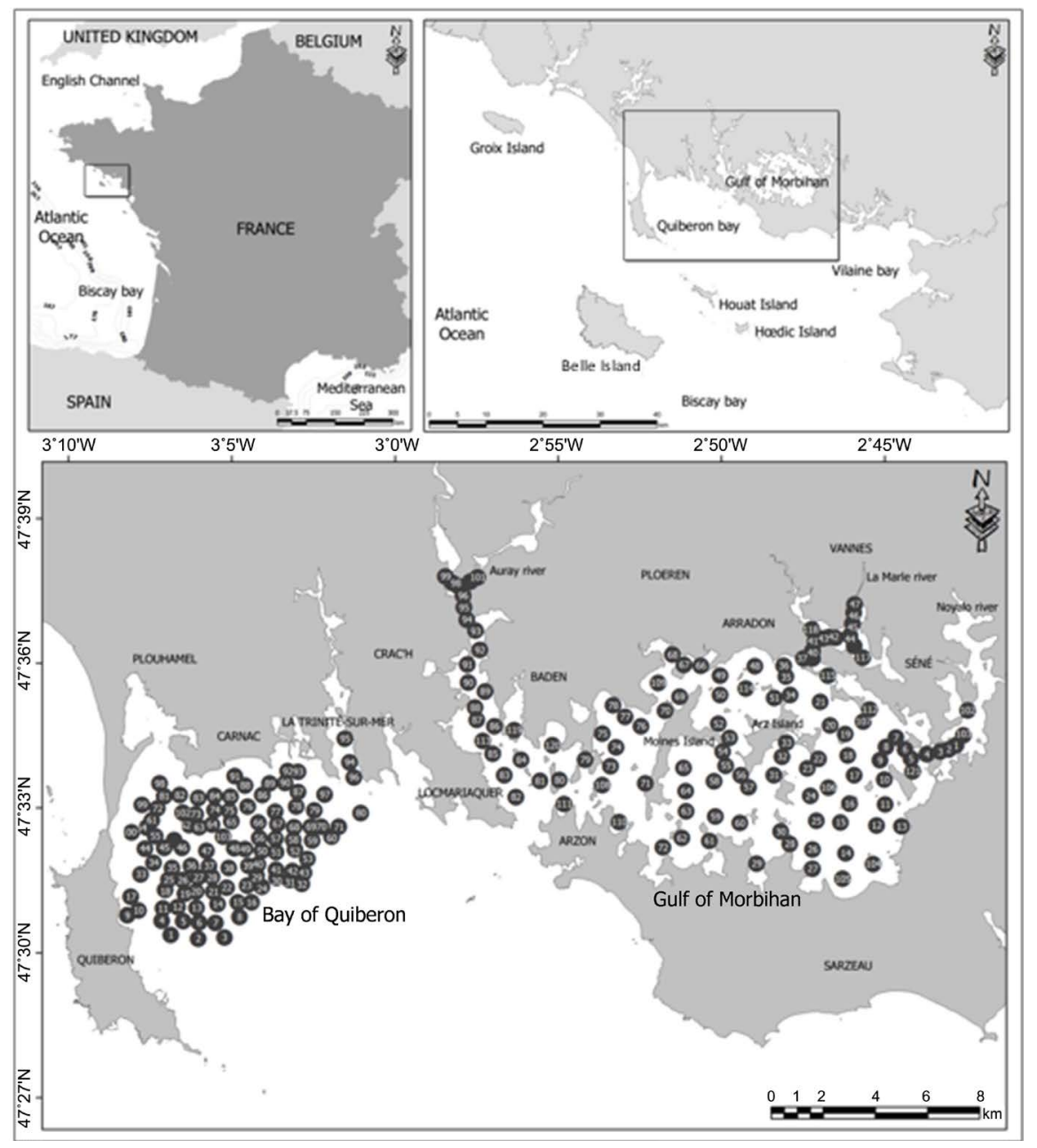

Figure 1. Map showing surficial sediment sampling points in South Brittany waters.

The tide is semi-diurnal with a mean spring tidal range of $4.5 \mathrm{~m}$. The tidal were stronger in the vicinity of the coast and especially in the passage between the Quiberon peninsula and neighboring Houat and Hœdic islands, and are amplified in shallower water depths [31] [32]. Due to this water physical characteristic, the outer bay was much influenced by the strong water current and tidal wave compared to the inner bay.

The Gulf of Morbihan ("Morbihan" = "little sea" in Breton) is a natural harbor located in the South Brittany, northwest France (Figure 1). It is a close sea body (11,500 ha) and a shoreline of $250 \mathrm{~km}$ [33]. It is a shallow basin with a maximum depth of $30 \mathrm{~m}$ and is connected to the sea by a $900 \mathrm{~m}$ wide and $30 \mathrm{~m}$ deep tidal inlet at Port Novalo [34]. Institut Géographique National recorded that there are 37 islands located in the gulf where the two largest islands are Moine and Arz Islands. The gulf is sheltered from the Atlantic Ocean (Biscay bay) by the peninsula of Quiberon, Houat, Hoëdic, and Belle Islands.

Across the gulf entrance, strong tidal currents affect the basin with water speeds that can reach $2.2 \mathrm{~m} / \mathrm{s}$ during ebb tides and $1.8 \mathrm{~m} / \mathrm{s}$ during flood tide. This gulf has a semidiurnal tidal regime with freshwater input from Auray, La 
Marle and Noyalo rivers [33]. The further from the entrance, the lower tidal range; $3 \mathrm{~m}$ at the eastern part and $5 \mathrm{~m}$ at the gulf entrance. Hence, tides are hypersynchronous, a characteristic feature of tidal dominated environments [35].

Many areas along the coast are used by the public as recreation areas. A number of shipping ports for recreational purposes and fishing activities are located in this region. In addition, the surrounding coast is successfully used for commercial shellfish (oyster and mussel) mariculture activities with a significant market around the region.

\subsection{Sample Collection}

This oceanographic fieldwork was carried out by the SEPIOLA research vessel of the University of Rennes1 at the Gulf of Morbihan and vessel of the Regional Committee of Conchyliculture (CRC), South Brittany at the Bay of Quiberon. A total of 196 surficial sediments were collected randomly in Bay of Quiberon and Gulf of Morbihan with Orange Peel Grab sampler. In addition, in order to prevent metals contamination from the wall of the grab, the outermost layer of the sediment samples were removed and only the inner part was kept for further analysis. After collected, the samples were stored in plastic containers and kept at low temperatures until analysis was carried out.

\subsection{Laboratory Analysis}

Sediment samples were digested and analyses for total heavy metals following published methodologies with some modifications [36] [37] [38] [39]. The digestion method involved heating of $50 \mathrm{mg}$ of a finely powdered sample in a sealed Teflon vessel in a mixture with a mixed acid solution of concentrated HF, $\mathrm{HNO}_{3}$ and $\mathrm{HCl}$. The Teflon vessel was kept in an oven at $100^{\circ} \mathrm{C}$ for 8 hours. After cooling at room temperature, the solution of the vessel was transferred into a polypropylene test tube. An inductively coupled plasma mass spectrometer (Perkin Elmer Elan 9000) was used for the quick and precise determination of selected heavy metals in the digested sediment samples. The accuracy was also examined by analyzing duplicate Standard Reference Material 1646a Estuarine Sediment, the results of which were within $\pm 3 \%$ of certified values.

\section{Results and Discussion}

All the analyzed data were visualized using ArcGIS software and presented in the form of a concentration isopleth map to identify the sediment concentration hotspot as shown in Figure 2. Visualization by overlaying maps using a geographical information system makes this presentation even easier and more successful [40]. Generally, all studied metals' concentrations were higher in the Gulf of Morbihan compared to Bay of Quiberon waters. On the other hand, the inner part of both Gulf of Morbihan and Bay of Quiberon area with low and limited water circulation, also exhibit higher metals concentration. 


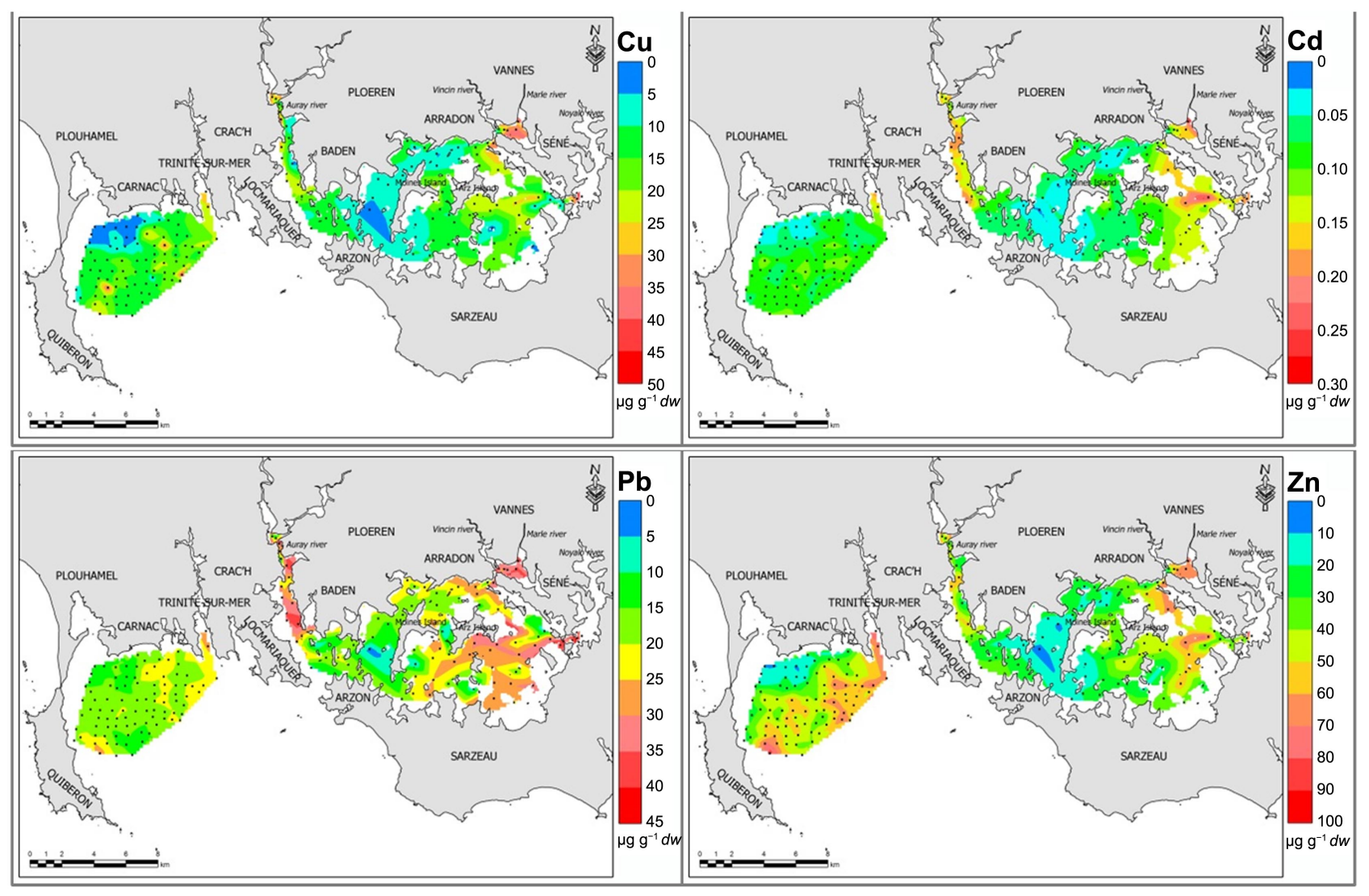

Figure 2. Concentration map for heavy metals distribution in South Brittany coastal waters surficial sediment.

Tomlison et al. [41] elaborated that the application of the pollution load index (PLI) provides a simple way to assess the quality of estuarine and coastal sediment. This assessment is a quick tool for comparing the status of pollution at different locations [42]. PLI represents the number of times the concentration of heavy metals in the sediment exceeds the background concentration and provides a summary indication of the overall level of heavy metal toxicity in a particular sample or location [43]. The PLI can provide the public in the surrounding area with some understanding of the quality of the components in their environment, indicating the trend both spatially and temporarily [44]. In addition, it provides valuable information to decision-makers towards better management of pollution levels in the Bay of Quiberon and Gulf of Morbihan regions.

PLI is obtained as contamination factors (CF). This CF is the quotient obtained by dividing the concentration of each metal with the background value of the metal. The PLI can be expressed in the following calculation:

$$
\text { Pollution load index }(\mathrm{PLI})=\left(\mathrm{CF}_{1} \times \mathrm{CF}_{2} \times \mathrm{CF}_{3} \times \mathrm{CF}_{n}\right)^{1 / n}
$$

where, $n$ is the number of metals ( 4 in the present study) and CF is the contamination factor. The CF can be calculated from:

$$
\text { Contamination Factor }(\mathrm{CF})=\frac{\text { Element concentartion in the sediment }}{\text { Background value of the element }}
$$


The PLI value $>1$ is categorized as polluted, while $<1$ indicates no pollution at the sampling point [45] [46].

PLI values of the analyzed surficial sediments were visualized by ArcGIS software and shown in Figure 3, which confirms that either Bay of Quiberon or Gulf of Morbihan is not seriously polluted with the heavy metals studied. PLI was found to be generally low $(<1)$ in all the studied locations in the Bay of Quiberon, apart from Trinité-sur-Mer area. The eastern zone and rivers (Auray, Marle and Noyalo) zones also have a PLI value above 1; therefore these areas can be classified as moderate contamination factors [46].

Two approaches were used to assess sediment toxicity and ecological risk to benthic organisms for heavy metals studied in Bay of Quiberon and Gulf of Morbihan surficial sediments. The first approach was to compare the concentrations of heavy metals to the Sediment Quality Guidelines (SQGs) promulgated by the United States Environmental Protection Agency (USEPA) which were reviewed by Giesy et al. [47]. This approach was used only to screen contaminants of concern in aquatic ecosystems. On the other hand, the second approach was to apply two sets of SQGs developed for marine and estuarine ecosystems [48] to the assessment the ecotoxicology of the concentration of heavy metals in sediments, namely, 1) the effect range low (ERL)/effect range median (ERM) and 2) the threshold effect level (TEL)/probable effect level (PEL).

Based on the SQGs proposed by USEPA from Giesy et al. [47], sediment contamination is defined as three classes, non-polluted, moderately polluted and heavily polluted (Table 1). This classification of SQGs does consider the natural background or multiple elements [49]. By comparing the mean concentrations of heavy metals in Bay of Quiberon and Gulf of Morbihan surficial sediments with SQGs, sediments in both areas were classified as non-polluted for $\mathrm{Zn}$, and $\mathrm{Pb}$, and moderately polluted by $\mathrm{Cu}$ and $\mathrm{Cd}$ where these metals exceed SQGs. Surficial sediments from Trinité-sur-Mer zone in Bay of Quiberon, Auray, Marle, Noyalo river zones, and the eastern in Gulf of Morbihan catchment area

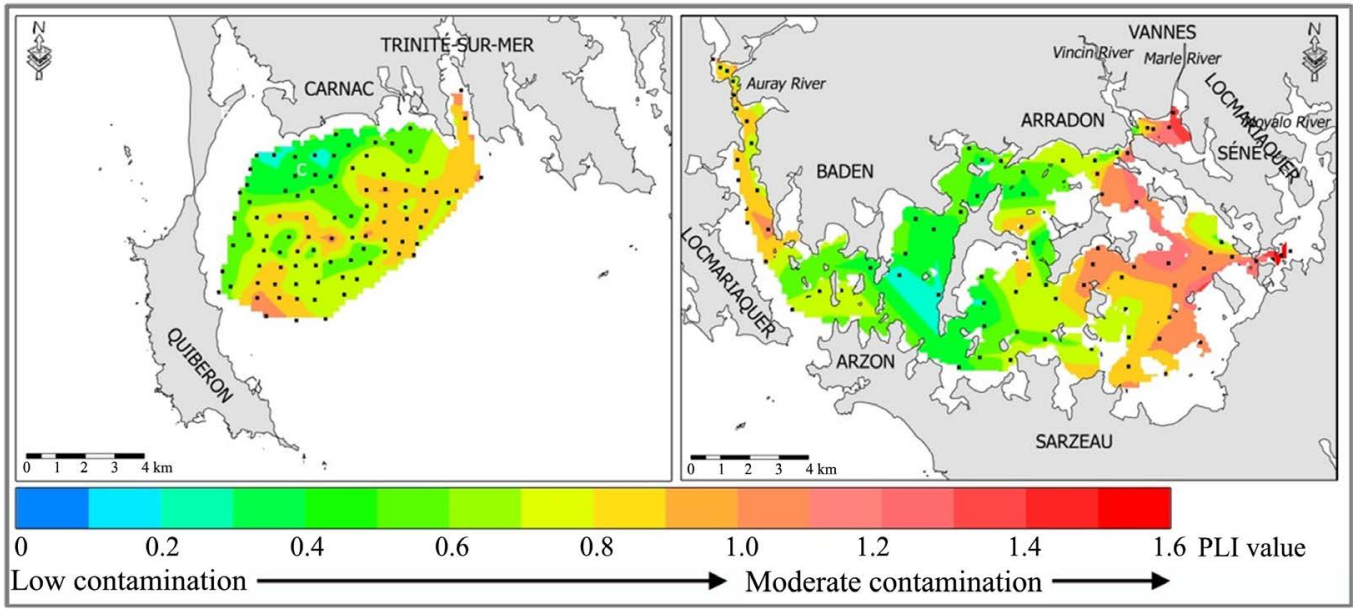

Figure 3. Contamination category based on PLI values in Bay of Quiberon and Gulf of Morbihan surficial sediments. 
Table 1. Classification of sediment samples $\left(\mu \mathrm{g} \cdot \mathrm{g}^{-1}\right)$ based on the proposed SQGs by USEPA.

\begin{tabular}{cccccccc}
\hline & \multicolumn{2}{c}{ Bay of Quiberon } & \multicolumn{2}{c}{ Gulf of Morbihan } & \multicolumn{3}{c}{ Sediment Quality Guidelines (SQGs) } \\
\hline & Mean & Min - Max & Mean & Min - Max & $\begin{array}{c}\text { Non } \\
\text { Polluted }\end{array}$ & $\begin{array}{c}\text { Moderately } \\
\text { Polluted }\end{array}$ & $\begin{array}{c}\text { Heavily } \\
\text { polluted }\end{array}$ \\
\hline $\mathrm{Cu}$ & 14.4 & $2.56-40.9$ & 21.9 & $1.20-48.6$ & $<25$ & $25-50$ & $>50$ \\
$\mathrm{Zn}$ & 40.7 & $4.60-98.9$ & 38.4 & $4.78-89.9$ & $<90$ & $90-200$ & $>200$ \\
$\mathrm{Cd}$ & 0.07 & $0.01-0.19$ & 0.11 & $0.01-0.30$ & - & - & $>6$ \\
$\mathrm{~Pb}$ & 15.1 & $3.61-28.0$ & 23.8 & $2.43-42.7$ & $<40$ & $40-60$ & $>60$ \\
\hline
\end{tabular}

were moderately enriched with these metals. However, no surficial sediments from both sampling areas were classified as heavily polluted with the heavy metals studied according to SQGs classification.

The concentration of heavy metals was evaluated in a screening-level ecological risk assessment by comparing them to another numerical SQGs, namely the threshold effect level (TEL)/probable effect level (PEL), and the effect range low (ERL)/effect range medium (ERM) which were proposed by Long and McDonald [50]. Low range values (i.e., ERL and TEL) are less than expected to have adverse effects on sediment dwelling fauna. In contrast, ERM and PEL represent chemical concentrations above which adverse effects are likely to occur in the aquatic ecosystem [50].

The SQG values for heavy metals studied in the surficial sediments from the Bay of Quiberon and Gulf of Morbihan and the sediment classification based on these guidelines are shown in Table 2. Results of SQGs classification suggest that all heavy metals in sediments would rarely be expected to cause adverse effects on biota that living in the area.

The majority of heavy metals studied did not exceed the corresponding ERL and TEL guideline values and therefore do not pose a risk to marine organisms living in Bay of Quiberon and Gulf of Morbihan. Only a small percentage of surficial sediments would be classified as possibly posing an occasional threat to the organism due to concentrations of $\mathrm{Cu}$. However, $\mathrm{Cr}, \mathrm{Cu}$, and $\mathrm{Pb}$ in a certain location exceeded the TEL value, particularly from the Gulf of Morbihan surficial sediments. Thus, at a concentration greater than the TEL, the toxic effect of long-term exposure to these heavy metals would be predicted to occur in the station sampled.

In order to estimate the effect of multiple contaminations on heavy metals, mean-ERM-quotient (M-ERM-Q) was calculated for each surficial sediment in the Bay of Quiberon and Gulf of Morbihan according to Tessier et al. [27], Long et al. [48] and Larrose et al. [51] as follows:

$$
\mathrm{M}-\mathrm{ERM}-\mathrm{Q}=\frac{\sum_{i=1}^{n}\left(C_{i} / \mathrm{ERM}_{i}\right)}{n}
$$

where $C_{i}$ is the surficial sediment concentrations of element $(i), \mathrm{ERM}_{i}$ is the 
Table 2. Classification of sediment samples based on the SQGs.

\begin{tabular}{|c|c|c|c|c|c|c|c|c|}
\hline & \multicolumn{4}{|c|}{ SQGs $\left(\mu \mathrm{g} \cdot \mathrm{g}^{-1}\right)$} & \multicolumn{4}{|c|}{ Percentage of the samples exceeding SQGs (\%) } \\
\hline & ERL & ERM & TEL & PEL & ERL & ERL-ERM & TEL & TEL-PEL \\
\hline \multicolumn{9}{|c|}{ Bay of Quiberon } \\
\hline $\mathrm{Cu}$ & 34 & 270 & 18.7 & 108.2 & 97 & 3 & 75 & 25 \\
\hline $\mathrm{Zn}$ & 150 & 410 & 124 & 271 & 100 & 0 & 100 & 0 \\
\hline $\mathrm{Cd}$ & 1.2 & 9.6 & 0.68 & 4.2 & 100 & 0 & 100 & 0 \\
\hline $\mathrm{Pb}$ & 46.7 & 218 & 30.2 & 112.2 & 100 & 0 & 100 & 0 \\
\hline \multicolumn{9}{|c|}{ Gulf of Morbihan } \\
\hline $\mathrm{Cu}$ & 34 & 270 & 18.7 & 108.2 & 85.1 & 14.9 & 38.3 & 61.7 \\
\hline $\mathrm{Zn}$ & 150 & 410 & 124 & 271 & 100 & 0 & 100 & 0 \\
\hline $\mathrm{Cd}$ & 1.2 & 9.6 & 0.68 & 4.2 & 100 & 0 & 100 & 0 \\
\hline $\mathrm{Pb}$ & 46.7 & 218 & 30.2 & 112.2 & 100 & 0 & 78.4 & 21.6 \\
\hline
\end{tabular}

ERM for element (i) and $\mathrm{n}$ is the number of elements, e.g. four heavy metals in this study.

Long et al. [48] have defined several classes of toxicity probability for biota organisms in their study from US coast based on amphipod survival test: m-ERM-Q $<0.1$ has a 9\% probability of toxicity); $0.1<$ m-ERM-Q $<0.5$ has a $21 \%$ probability of being toxic; $0.5<\mathrm{m}$-ERM-Q $<1.5$ has a $49 \%$ of being toxic; and $\mathrm{m}-\mathrm{ERM}-\mathrm{Q}>1.5$ has a $76 \%$ probability of toxicity. Using the concentrations of the heavy metals studied, the m-ERM-Q value was calculated, and the obtained distribution visualized by ArcGIS software in Bay of Quiberon and Gulf of Morbihan is shown in Figure 4.

The $\mathrm{m}-\mathrm{ERM}-\mathrm{Q}$ distribution pattern in the Bay of Quiberon surficial sediments showed that the inner bay zone had values below 0.1, which indicated a $9 \%$ probability of being toxic to the benthic organisms in that area. In the outer bay, the $\mathrm{m}$-ERM-Q values slightly exceed 0.1 , but not more than 0.2 indicate that this zone is between $9 \%$ and $21 \%$ probability to be toxic to benthic organisms. However, in Trinité-sur-Mer area, m-ERM-Q ranged from 0.2 and 0.3 ; therefore, this area can be categorized as $21 \%$ probability of toxicity to the benthic organisms according to Long et al. [48] classification.

Meanwhile, in the gulf of Morbihan sediments, the $\mathrm{m}-\mathrm{ERM}-\mathrm{Q}$ values at the western zone of the gulf were lower than $0.1 \mathrm{~m}$, and therefore this zone can be categorized as $9 \%$ probability of being toxic to the benthic organisms. Towards the inner gulf of eastern zone, the values of $\mathrm{m}-\mathrm{ERM}-\mathrm{Q}$ were increased but do not exceed the $21 \%$ probability of toxicity to the benthic organisms, 0.2 . Generally, some sampling locations located at the rivers zone (Auray, Marle and Noyalo) had the m-ERM-Q value higher than 0.3 , which meant a $21 \%$ probability of toxicity to the benthic organisms. The impact of contaminated sediment probably on aquatic ecosystems is likely to be due to re-suspension and remobilization processes [52] [53]. 


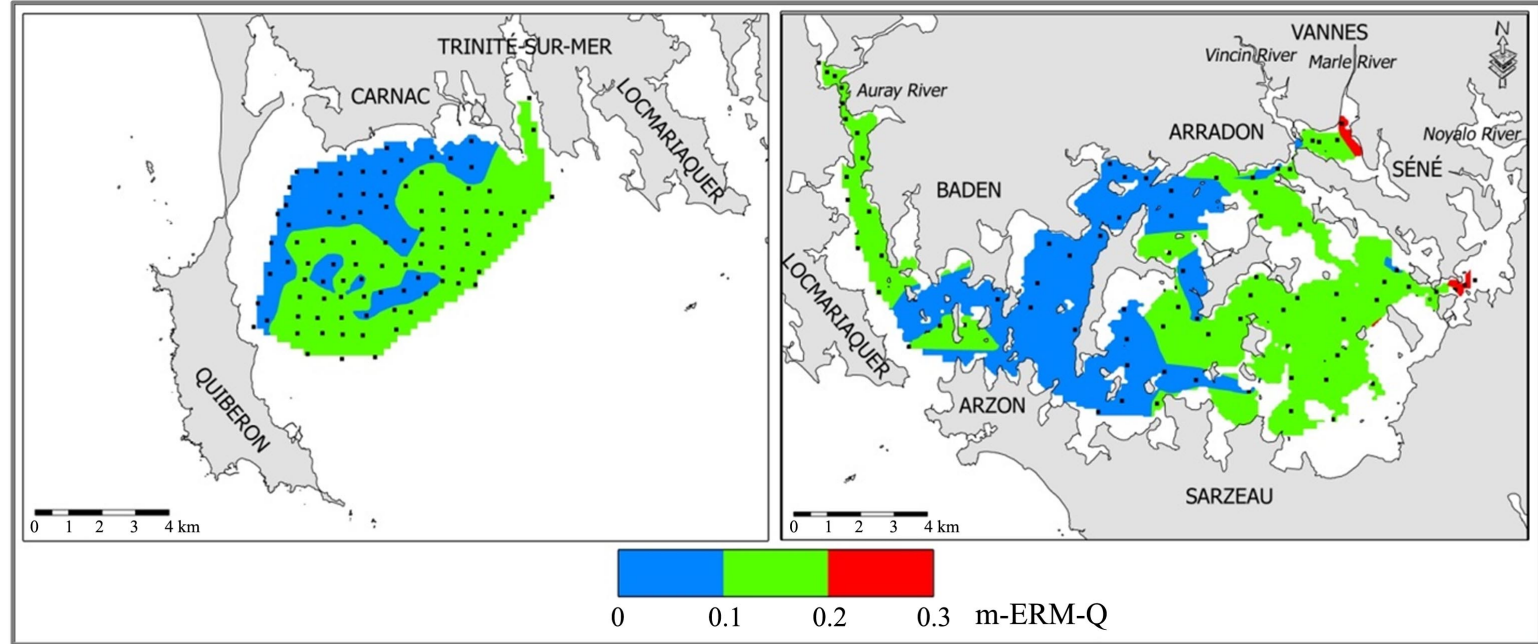

Figure 4. Contamination category based on m-ERM-Q values in Bay of Quiberon and Gulf of Morbihan surficial sediments.

\section{Conclusion}

In comparison with the sediment quality guidelines for the ecological risk assessment, generally, all metals studied were not exceeding the ERL and PEL classification. Hence, these metals were considered not toxic to the marine organisms. The multiple contamination evaluation by mean-ERM-quotient shows that the sediments do not have more than $21 \%$ probability of being toxic to the aquatic organism. However, it is suggested that continuous monitoring including other pollutants such as hydrocarbons, microplastics, nutrient and pharmaceutical wastes should be implemented as the site is important for the recreation area, fishing and oysters mariculture activities.

\section{Acknowledgements}

The authors wish to acknowledge their gratitude to the anonymous reviewers who gave freely time and effort, constructive recommendations that enhanced the value of this manuscript. The authors also would like to thank Mr. Joseph Bidai for his assistance in the detection of heavy metals using ICPMS at Institute of Oceanography and Environment.

\section{Conflicts of Interest}

The authors declare no conflicts of interest regarding the publication of this paper.

\section{References}

[1] Halpern, B.S., Walbridge, S., Selkoe, K.A., Kappel, C.V., Micheli, F., D’Agrosa, C., et al. (2008) A Global Map of Human Impact on Marine Ecosystems. Science, 319, 948-952. https://doi.org/10.1126/science.1149345

[2] Halpern, B.S., Frazier, M., Afflerbach, J., Lowndes, J.S., Micheli, F., O’Hara, C., Scarborough, C. and Selkoe, K.A. (2019) Recent Pace of Change in Human Impact 
on the World's Ocean. Scientific Report, 9, Article No. 11609. https://doi.org/10.1038/s41598-019-47201-9

[3] El Zrelli, R., Courjault-Radé, P., Rabaoui, L., Castet, S., Michel, S. and Bejaoui, N. (2015) Heavy Metal Contamination and Ecological Risk Assessment in the Surface Sediments of the Coastal Area Surrounding the Industrial Complex of Gabes City, Gulf of Gabes, SE Tunisia. Marine Pollution Bulletin, 101, 922-929. https://doi.org/10.1016/j.marpolbul.2015.10.047

[4] Jones, K.R., Klein, C.J., Halpern, B.S., Venter, O., Grantham, H., Kuempel, C.D., Shumway, N., Friedlander, A.M., Possingham, H.P. and Watson, J.E.M. (2018) The Location and Protection Status of Earth's Diminishing Marine Wilderness. Current Biology, 28, 2506-2512. https://doi.org/10.1016/j.cub.2018.06.010

[5] Kennish, M.J. (2002) Environmental Threats and Environmental Future of Estuaries. Environmental Conservation, 29, 78-107.

https://doi.org/10.1017/S0376892902000061

[6] Bay, S.M., Zeng, E.Y., Lorenson, T.D., Tran, K. and Alexander, C. (2003) Temporal and Spatial Distributions of Contaminants in Sediments of Santa Monica Bay, California. Marine Environmental Research, 56, 255-276.

https://doi.org/10.1016/S0141-1136(02)00334-3

[7] Wojciechowska, E., Nawrot, N., Walkusz-Miotk, J., Matej-Łukowicz, K. and Pazdro, K. (2019) Heavy Metals in Sediments of Urban Streams: Contamination and Health Risk Assessment of Influencing Factors. Sustainability, 11, 563. https://doi.org/10.3390/su11030563

[8] Sobihah, N.N., Zaharin, A.A., Nizam, M.K. and Juen, L.L. (2018) Bioaccumulation of Heavy Metals in Maricultured Fish, Lates calcarifer (Barramudi), Lutjanus campechanus (Red Snapper) and Lutjanus griseus (Grey Snapper). Chemosphere, 197, 318-324. https://doi.org/10.1016/j.chemosphere.2017.12.187

[9] Tengku Nur Alia, T.K.A., Hing, L.S., Sim, S.F., Pradit, S., Ahmad, A. and Ong, M.C. (2020) Comparative Study of Raw and Cooked Farmed Sea Bass (Lates calcarifer) in Relation to Metal Content and Its Estimated Human Health Risk. Marine Pollution Bulletin, 153, Article ID: 111009. https://doi.org/10.1016/j.marpolbul.2020.111009

[10] Benali, I., Boutiba, Z., Grandjean, D., de Alencastro, L.F., Rouane-Hacene, O. and Chèvre, N. (2017) Spatial Distribution and Biological Effects of Trace Metals $(\mathrm{Cu}$, $\mathrm{Zn}, \mathrm{Pb}, \mathrm{Cd}$ ) and Organic Micropollutants (PCBs, PAHs) in Mussels Mytilus galloprovincialis along the Algerian West Coast. Marine Pollution Bulletin, 115, 539-550. https://doi.org/10.1016/j.marpolbul.2016.12.028

[11] Gu, Y.G., Ning, J.J., Ke, C.L. and Huang, H.H. (2018) Bioaccessibility and Human Health Implications of Heavy Metals in Different Trophic Level Marine Organisms: A Case Study of the South China Sea. Ecotoxicology and Environmental Safety, 163, 551-557. https://doi.org/10.1016/j.ecoenv.2018.07.114

[12] Gu, Y.G., Lin, Q., Huang, H.H., Wang, L.G., Ning, J.J. and Du, F.Y. (2017) Heavy Metals in Fish Tissues/Stomach Contents in Four Marine Wild Commercially Valuable Fish Species from the Western Continental Shelf of South China Sea. Marine Pollution Bulletin, 114, 1125-1129. https://doi.org/10.1016/j.marpolbul.2016.10.040

[13] Bonsignore, M., Manta, D.S., Mirto, S., Quinci, E.M., Ape, F., Montalto, V., Gristina, M., Traina, A. and Sprovieri, M. (2018) Bioaccumulation of Heavy Metals in Fish, Crustaceans, Molluscs and Echinoderms from the Tuscany Coast. Ecotoxicology and Environmental Safety, 162, 554-562. https://doi.org/10.1016/j.ecoenv.2018.07.044

[14] Ali, H. and Khan, E. (2019) Trophic Transfer, Bioaccumulation, and Biomagni- 
fication of Non-Essential Hazardous Heavy Metals and Metalloids in Food Chains/Webs-Concepts and Implications for Wildlife and Human Health. Human and Ecological Risk Assessment, 25, 1353-1376. https://doi.org/10.1080/10807039.2018.1469398

[15] Caito, S. and Aschner, M. (2017) Developmental Neurotoxicity of Lead. Advances in Neurobiology, 18, 3-12. https://doi.org/10.1007/978-3-319-60189-2_1

[16] Aoshima, K. (2016) Itai-Itai Disease: Renal Tubular Osteomalacia Induced by Environmental Exposure to Cadmium-Historical Review and Perspectives. Soil Science and Plant Nutrition, 62, 319-326. https://doi.org/10.1080/00380768.2016.1159116

[17] Ogawa, T., Kobayashi, E., Okubo, Y., Suwazono, Y., Kido, T. and Nogawa, K. (2004) Relationship among Prevalence of Patients with Itai-Itai Disease, Prevalence of Abnormal Urinary Findings, and Cadmium Concentrations in Rice of Individual Hamlets in the Jinzu River Basin, Toyama Prefecture of Japan. International Journal of Environmental Health Research, 14, 243-252. https://doi.org/10.1080/09603120410001725586

[18] Roosenburg, W.H. (1969) Greening and Copper Accumulation in the American Oyster, Crassostrea virginica, in the Vicinity of a Steam Electric Generating Station. Chesapeake Science, 10, 241-252. https://doi.org/10.2307/1350461

[19] Funes, V., Alhama, J., Navas, J.I., López-Barea, J. and Peinado, J. (2006) Ecotoxicological Effects of Metal Pollution in Two Mollusc Species from the Spanish South Atlantic littoral. Environmental Pollution, 139, 214-223. https://doi.org/10.1016/j.envpol.2005.05.016

[20] Ji, C., Wang, Q., Wu, H., Tan, Q. and Wang, W.X. (2016) A Metabolomic Study on the Biological Effects of Metal Pollutions in Oysters Crassostrea sikamea. Marine Pollution Bulletin, 102, 216-222. https://doi.org/10.1016/j.marpolbul.2015.11.037

[21] Wang, W.X., Yang, Y., Guo, X., He, M., Guo, F. and Ke, C. (2011) Copper and Zinc Contamination in Oysters: Subcellular Distribution and Detoxification. Environmental Toxicology and Chemistry, 30, 1767-1774. https://doi.org/10.1002/etc.571

[22] Fang, T.H. and Dai, S.Y. (2017) Green Oysters Occurring in an Industrial Harbor in Central Taiwan. Marine Pollution Bulletin, 124, 1006-1013.

https://doi.org/10.1016/j.marpolbul.2017.02.059

[23] Gao, H., Bai, J., Xiao, R., Liu, P., Jiang, W. and Wang, J. (2013) Levels, Sources and Risk Assessment of Trace Elements in Wetland Soils of a Typical Shallow Freshwater Lake, China. Stochastic Environmental Research and Risk Assessment, 27, 275-284. https://doi.org/10.1007/s00477-012-0587-8

[24] Duruibe, J.O., Ogwuegbu, M. and Egwurugwu, J. (2007) Heavy Metal Pollution and Human Biotoxic Effects. International Journal of Physical Sciences, 2, 112-118.

[25] Shimada, H., Funakoshi, T. and Waalkes, M.P. (2000) Acute, Nontoxic Cadmium Exposure Inhibits Pancreatic Protease Activities in the Mouse. Toxicological Sciences, 53, 474-480. https://doi.org/10.1093/toxsci/53.2.474

[26] Dauvalter, V. and Rognerud, S. (2001) Heavy Metal Pollution in Sediments of the Pasvik River Drainage. Chemosphere, 42, 9-18.

https://doi.org/10.1016/S0045-6535(00)00094-1

[27] Tessier, E., Garnier, C., Mullot, J.U., Lenoble, V., Arnaud, M., Raynaud, M. and Mounier, S. (2011) Study of the Spatial and Historical Distribution of Sediment Inorganic Contamination in the Toulon Bay (France). Marine Pollution Bulletin, 62, 2075-2086. https://doi.org/10.1016/j.marpolbul.2011.07.022

[28] Masson, M., Blanc, G. and Schäfer, J. (2006) Geochemical Signals and Sources Contributions to Heavy Metal $(\mathrm{Cd}, \mathrm{Zn}, \mathrm{Pb}, \mathrm{Cu})$ Fluxes into the Gironde Estuary via Its 
Major Tributaries. Science of the Total Environment, 370, 133-146. https://doi.org/10.1016/j.scitotenv.2006.06.011

[29] Proust, J.N., Menier, D., Guillocheau, F., Guennoc, P., Bonnet, S., Rouby, D. and Le Corre, C. (2001) Les vallées fossiles de la baie de la vilaine: Nature et évolution du prisme sédimentaire côtier du pleistocène armoricain. Bulletin de la Société Géologique de France, 172, 737-749. https://doi.org/10.2113/172.6.737

[30] Chaumillon, E., Bertin, X., Falchetto, H., Allard, J., Weber, N., Walker, P., Pouvreau, N. and Woppelmann, G. (2008) Multi Time-Scale Evolution of a Wide Estuary Linear Sandbank, the Longe de Boyard, on the French Atlantic Coast. Marine Geology, 251, 209-223. https://doi.org/10.1016/j.margeo.2008.02.014

[31] Pinot, J.P. (1974) Le port continent breton entre Penmarc'h, Belle-Ile et I'escarpement continental, ttude geomorphologi-que. Lannion. Imfram, $256 \mathrm{p}$.

[32] Vanney, J.R. (1977) Géomorphologie de la marge continentale sudarmoricaine. Société d'édition d'enseignement supérieur, Paris, $473 \mathrm{p}$.

[33] Menier, D., Tessier, B., Dubois, A., Goubert, E. and Sedrati, M. (2011) Geomorphological and Hydrodynamic Forcing of Sedimentary Bedforms-Example of Gulf of Morbihan (South Brittany, Bay of Biscay). Journal of Coastal Research, 64, 1530-1534.

[34] Rossi, V., Horton, B.P., Corbett, D.R., Leorri, E., Perez-Belmonte, L. and Douglas, B.C. (2011) The Application of Foraminifera to Reconstruct the Rate of 20th Century Sea Level Rise, Morbihan golfe, Brittany, France. Quaternary Research, 75, 24-35. https://doi.org/10.1016/j.yqres.2010.07.017

[35] Dalrymple, R.W. and Choi, K. (2006) Morphologic and Facies Trends through the Fluvial-Marine Transition in Tide-Dominated Depositional Systems: A Schematic Framework for Environmental and Sequence Stratigraphic Interpretation. Earth-Science Reviews, 81, 135-174. https://doi.org/10.1016/j.earscirev.2006.10.002

[36] Kamaruzzaman, B.Y., Nurulnadia, M.Y., Shazili, N.A.M., Ong, M.C., Shahbudin, S., Jalal, K.C.A. and Joseph, B. (2011) Heavy Metal Concentration in the Surface Sediment of Tanjung Lumpur Mangrove Forest, Kuantan, Malaysia. Sains Malaysiana, 40, 89-92.

[37] Kamaruzzaman, B.Y., Siti Waznah, A., Ong, M.C. and Joseph, B. (2010) Spatial Distribution of Lead and Copper in the Bottom Sediments of Pahang River Estuary, Pahang, Malaysia. Sains Malaysiana, 39, 543-547.

[38] Ong, M.C., Menier, D., Shazili, N.A.M. and Dupont, V. (2012) Geochemistry of Metallic Trace Elements in Surficial Sediments of the Gulf of Morbihan, Brittany, France. Journal of Applied Sciences, 12, 2215-2224. https://doi.org/10.3923/jas.2012.2215.2224

[39] Ong, M.C., Joseph, B., Shazili, N.A.M., Ghazali, A. and Mohamad, M.N. (2015) Heavy Metals Concentration in Surficial Sediments of Bidong Island, South China Sea off the East Coast of Peninsular Malaysia. Asian Journal of Earth Science, 8, 74-82. https://doi.org/10.3923/ajes.2015.74.82

[40] Caeiro, S., Costa, M.H., Ramos, T.B., Fernandes, F., Silveira, N., Coimbra, A., Medeiros, G. and Painho, M. (2005) Assessing Heavy Metal Contamination in Sado Estuary Sediment: An Index Analysis Approach. Ecological Indicators, 5, 151-169. https://doi.org/10.1016/j.ecolind.2005.02.001

[41] Tomlinson, D.L., Wilson, C.R., Harris, C.R. and Jeffrey, D.W. (1980) Problems in the Assessment of Heavy-Metal Levels in the Estuaries and the Formation of a Pollution Index. Hergoland Marine Research, 33, 566-575. https://doi.org/10.1007/BF02414780

[42] Karbassi, A.R., Bayati, I. and Moatta, F. (2006) Origin and Chemical Partitioning of 
Heavy Metals in Riverbed Sediments. International Journal of Environmental Science \& Technology, 3, 35-42. https://doi.org/10.1007/BF03325905

[43] Rabee, A.M., Al-Fatlawy, Y.F., Najim, A.A. and Nameer, M. (2011) Using Pollution Load Index (PLI) and Geoaccumulation Index (I-geo) for the Assessment of Heavy Metals Pollution in Tigris River Sediment in Baghdad Region. Journal of Al-Nahrain University, 14, 108-114. https://doi.org/10.22401/JNUS.14.4.14

[44] Harikumar, P.S. and Jisha, T.S. (2010) Distribution Pattern of Trace Metal Pollutants in the Sediments of an Urban Wetland in the Southwest Coast of India. International Journal of Engineering Science and Technology, 2, 840-850.

[45] Chakravarty, M. and Patgiri, A.D. (2009) Metal Pollution Assessment in Sediments of the Dikrong River, NE India. Journal of Human Ecology, 27, 63-67. https://doi.org/10.1080/09709274.2009.11906193

[46] Seshan, B.R.R., Natesan, U. and Deepthi, K. (2010) Geochemical and Statistical Approach for Evaluation of Heavy Metal Pollution in Core Sediments in Southeast Coast of India. International Journal of Environmental Science \& Technology, 7, 291-306. https://doi.org/10.1007/BF03326139

[47] Giesy, J.P. and Hoke, R.A. (1990) Freshwater Sediment Quality Criteria: Toxicity Bioassessment. In: Baudo, R., Giesy, J.P. and Muntau, H., Eds., Sediments. Chemistry and Toxicity of In-Place Pollutants, Lewis, Chelsea, 265-348.

[48] Long, E.R., Field, L.J. and MacDonald, D.D. (1998) Predicting Toxicity in Marine Sediments with Numerical Sediment Quality Guidelines. Environmental Toxicology and Chemistry, 17, 714-727. https://doi.org/10.1002/etc.5620170428

[49] Luo, W., Lu, Y.L., Wang, T.Y., Hu, W.Y., Jiao, W.T., Naile, J.E., Khim, J.S. and Giesy, J.P. (2010) Ecological Risk Assessment of Arsenic and Metals in Sediments of Coastal Areas of Northern Bohai and Yellow Seas, China. AMBIO, 39, 367-375. https://doi.org/10.1007/s13280-010-0077-5

[50] Long, E.R. and MacDonald, D.D. (1998) Recommended Uses of Empirically Derived, Sediment Quality Guidelines for Marine and Estuarine Ecosystems. Human and Ecological Risk Assessment: An International Journal, 4, 1019-1039. https://doi.org/10.1080/10807039891284956

[51] Larrose, A., Coynel, A., Schäfer, J., Blanc, G., Massé, L. and Maneux, E. (2010) Assessing the Current State of the Gironde Estuary by Mapping Priority Contaminant Distribution and Risk Potential in Surface Sediment. Applied Geochemistry, 25, 1912-1923. https://doi.org/10.1016/j.apgeochem.2010.10.007

[52] Tankere-Muller, S., Zhang, H., Davison, W., Finke, N., Larsen, O., Stahl, H. and Glud, R.N. (2007) Fine Scale Remobilization of Fe, Mn, Co, Ni, Cu and Cd in Contaminated Marine Sediment. Marine Chemistry, 106, 192-207.

https://doi.org/10.1016/j.marchem.2006.04.005

[53] Kalnejais, L.H., Martin, W.R. and Bothner, M.H. (2010) The Release of Dissolved Nutrients and Metals from Coastal Sediments Due to Resuspension. Marine Chemistry, 121, 224-235. https://doi.org/10.1016/j.marchem.2010.05.002 